\title{
Ebeveyn ve Akran İlişkilerinin Genç Kızlarda Madde Kullanımına Etkisi
}

Elif Yalman $^{1 *}$

Gelis tarihi: 06.03.2019

Kabul tarihi: 24.04.2019

\section{Atıf bilgisi:}

Uluslararası Bilimsel Araștırmalar Dergisi (IBAD)

Cilt: $4 \quad$ Sayı: 2

Sayfa: 372-391 Yll: 2019

Dönem: Yaz

This article was checked by Turnitin Similarity Index $12 \%$

1 İstanbul Üniversitesi, Türkiye, elifelifyalman@gmail.com, ORCID ID 0000-0002-5650-1264

\section{* Sorumlu yazar}

öz

Madde bağımlılı̆̆ hem ülkemizde hem de dünyanın birçok yerinde tehdit edici bir sorundur. Özellikle ergenlik ve gençlik döneminde gerek ailevi sebepler gerek akran baskısıyla başlanabilen ve bağımlılığa neden olan madde kullanımının bu iki alanla ilişkisi incelemeye değerdir. Genç kızların madde kullanım davranıșının sosyal çevre ile, özellikle akran ve ebeveynlerle ilişkisini anlamaya çalışmak amacıyla hazırlanan bu çalışmada, madde kullanan veya eski kullanıcı olan 9 genç kız ile görüșülmüștür. Araştırmacı tarafindan yarı yapılandırılmış görüşme soruları hazırlanmış ve katılımcıların rahat edebilecekleri bir ortam sağlanarak derinlemesine görüşme tekniğiyle mülakat yapılmıștır. Madde bağımlısı genç kızlara ulaşmada çekilen güçlüklerden dolayı madde bağımlılığı konusunda çalışan dernekler aracılığıyla birkaç katılımcıya ulaşılmıştır. Ayrıca ilaç yazdırmak için CCEMATEM tedavi merkezine gelen gençlerle de görüşülmüştür. Görüşme esnasında katılımcıların izniyle ses kaydı alınmış ve analiz edilerek bulgular kısmına aktarılmıștır. Görüşmelerden elde edilen sonuçlara göre madde kullanımında hem aile hem de akran ilişkilerinin önemli etkisi bulunmaktadır. Ailelerin gençlere karşı anlayışsız ve ilgisiz davranması onları ev dışındaki hayata yakınlaştırmakta ve olası tehlikelere daha açık hale getirmektedir. Aileden uzaklaşmasıyla birlikte akran gruplarına yakınlaşan genç bazen arkadaşlarının baskısına dayanamadığı bazen de merak ettiği ve özendiği için maddeyi deneyebilmektedir. Madde kullanımının bağımlılığa dönüşmesiyle maddeye ulaşmak isteyen gençler fiziksel ve duygusal bazı istismarlara maruz kalabilmektedir. Uzun süren gizli kullanımın ardından bir şekilde ailenin haberinin olmasıyla gençler madde kullanımını bırakma sürecine girmektedir. Katılımcıların ifadelerine göre ailelerin genellikle destekleyici olduğu ve bu süreçte gencin yanında olduğu söylenebilir.

Anahtar Kelimeler: Bağımlılık, Madde Bağımlılı̆̆ı, Ergenlik, Akran İlișkisi, Genç Kızlarda Bağımlılık 


\title{
The Effect Of Parent And Peer Relations On The Drug Use Of Young Girls
}

\author{
Elif Yalman
}

First received: 06.03.2019

Accepted: 24.04 .2019

\section{Citation:}

Journal of the International Scientific Research (IBAD)

Volume: 4 Issue: 2

Pages: 372-391 Year: 2019

Session: Summer

This article was checked by Turnitin. Similarity Index $12 \%$

1 İstanbul University, Turkey, elifelifyalman@gmail.com, ORCID ID 0000-0002-5650-1264

* Corresponding Author

\begin{abstract}
Drug addiction is a threatening problem both in our country and in many parts of the world. The relationship between these two fields, drug use and addiction-induced drug use, especially in adolescence and youth, which may start with familial reasons and peer pressure, are worth examining. In this study, which was prepared in order to understand how drug-addiction effected by peer and parents, were interviewed with 9 young girls who were drug abusers or exusers. Semi-structured interview questions were prepared and interviewed by researcher. Due to difficulties in accessing drug-addicted young girls, a number of participants were reached through associations that work related to drug addiction. In addition, young people from treatment center were interviewed too who came there for medicines. Also interview held with youths who came to the ÇEMATEM treatment centre for taking medicine. During the interview, audio recordings were taken with the permission of the participants and analyzed and transferred to the results section. According to the results obtained from the interviews, both family and peer relations have a significant effect on substance use. The insufficient and indifferent behavior of families towards young people brings them closer to the life outside the home and makes them more vulnerable to possible dangers. With her distancing from the family, the teenager who is close to the peer groups sometimes tries to use substance because she cannot stand the pressure of her friends and sometimes she may curious and intrigued. With the transformation of substance use into addiction, young people who want to reach the substance can be subject to some physical and emotional abuse. After a long period of confidential use, when the family is informed about the addiction, young people start in the process of quitting substance use. According to the statements of the participants, it can be said that families are generally supportive and that they are in the process.
\end{abstract}

Keywords: Addiction, Drug Addiction, Adolescent, Peer Relationship, Addiction in Young Girls 


\section{GİRIŞ}

Madde kullanımı genç kızlar arasında da yaygın olmasına rağmen madde kullanan kızlar bazı sebeplerden (toplumsal, sosyal, ailevi vb.) dolayı erkekler kadar ön planda değildir. Bu araştırma madde bağımlısı genç kızların hem maddeye başlama hem de kullanım ve bırakma sürecinde aile ve akranlarından nasıl etkilendiklerini anlamak amacıyla yapılmıştır. Madde kullanmış veya kullanmaya devam eden genç kızlarla yapılan görüşmeler sonucu elde edilen bulgular çalıșmada analiz edilmiștir. Bu ve benzeri çalışmalarla birlikte genç kızların madde kullanım sürecinde arkadaş ve ailenin etkisi anlaşılabilirse gerek koruyucu-önleyici çalışmalarda gerek rehabilitasyon sürecinde bu yönde gerekli tedbirlerin alınabileceği veya bırakma aşamasında destek sağlanabileceği düşünülmektedir.

\section{Ergenlik Dönemi}

Ergenlik için kesin bir yaş sınırından bahsetmek zordur. Ergenlik dönemine girme yaşı kişiden kişiye, toplumdan topluma ve kültürden kültüre değişiklik gösterebilmektedir. Örneğin Birleşmiş Milletler ergenlik yaşını 12-17 yaş olarak belirtmektedir (United Nations, 2012). Yörükoğlu'na göre ise ergenlik dönemi 12-21 yaş arasını kapsamaktadır (Yörükoğlu, 1978, s. 277).

\section{Ergen ve Aile İlișkisi}

Geniş aile yapısının ergen için kuşak çatışması durumu söz konusu olmakla birlikte, yetişkin sosyal davranışlarına ve sorumluluklarına karşı bir aşinalık kazanmada da faydalı olduğu söylenebilir. Bu durum ise ergenin kendisine ait yetenek ve sorumlulukları ögrenmesine yardımcı olmaktadır. Bununla birlikte son zamanlarda ergenlerin içinde yaşadıkları ailenin boyutu giderek küçülmektedir. Günümüzde geniş ailenin çekirdek aile modeline dönmesiyle ergen sadece anne-baba ile ilişki kurabilmektedir ve farklı yetişkin rollerini gözlemleme avantajını kaybetmektedir (Temel ve Aksoy, 2001, s. 86).

\section{Ergen ve Akran İlişkisi}

Ergenlik döneminin rahat atlatılabilmesi için bu dönemin sorunlaryyla baş edebilmek gerekmektedir. $\mathrm{Bu}$ birçok faktöre bağlıdır. En önemli faktörlerden biri ise akran ilişkileridir. "Akran; aynı sosyal gruptaki kişiler için kullanılır. Bu grup yaş, cinsiyet, cinsel yönelim, meslek sosyo-ekonomik durum ve/veya sağlık durumu gibi ortak özellikleri temel alabilir." (Bilgiç ve Günay, 2014, s. 103).

Akran Grubu; küçük, kapalı ve yakın arkadaşlığa dayanan gruptur. Kiminle arkadaş olunacağını çeşitli etkenler belirlemektedir. Çocuklukta ve ilk ergenlikte genç, arkadaşlarını çoğu zaman aynı mahalleden, aynı okuldan ve birbirini uzun zamandır tanıyan kişilerden seçer (Satan, 2011, s. 184).

Akran Baskısı; bireyin sahip olduğu akran grubunda herhangi bir aktiviteyi yerine getirmesi için ısrar edilmesi ve cesaretlendirilmesidir (Santor, 2000, s. 164). Ergenlik gibi aileden bağımsızlığın kazanıldığı bir dönemde sığınılacak yeni limanlar bulmak için ergenler akran gruplarına yönelir. Çünkü akran gruplarının üyeleri birbirleri için bir otorite değildir. Bu da ergenin akran grubunda kendini daha rahat ifade edebilmesi demektir. "Akranlar arkadaşları için tehdit edici değil, eğlendiricidir." (Bilgiç ve Günay, 2014, s. 104).

\section{Bağımlılık}

Madde bağımlılığını Bektaş "bağımlılık yapıcı maddenin uzun süre ya da kısa ve düzenli kullanılması durumunda bedenin bağımlılık yapıcı maddenin etkisine alışması, alışılan maddenin alınmaması ya da azaltılması durumunda ise, bedende yorgunluk belirtilerinin ortaya çıkması" şeklinde tanımlarken, Ögel "kişinin kullandığı maddeyi birçok kez bırakma girişiminde bulunmasına rağmen bırakamaması, giderek madde dozunu arttırması, kullanmayı bıraktığında yoksunluk belirtilerinin ortaya çıkması, zararlarını görmesine rağmen madde kullanmayı sürdürmesi, zamanının büyük bölümünü madde arayarak geçirmesi” olarak tanımlamaktadır (Bektaş, 1991; Ögel, 2001; akt. Erdamar ve Kurupınar, 2014, s. 66).

Alkol, kenevir, kokain, uçucu maddeler, sakinleştiriciler gibi merkezi sinir sistemini etkileyen ve bağımlılık yapan kimyasallara psikoaktif madde denir. Bağımlılık zarar verici sonuçlar doğurmasına karşın, etkin bir şekilde madde arama ve kullanma ile devam eden tekrarlayıcı bir beyin hastalığıdır (Ögel, 2002, s. 16). Bir maddenin uyuşturucu madde sayılıp sayılmayacağı söz konusu olduğunda kişide alışkanlık yaratması önemli kriterlerden biri olmaktadır. Ayrıca o maddenin uyarıcı, keyif verici, hayal 
doğurucu, tahrik ve sarhoş edici olup olmadığına, insan irade ve muhakemesini ortadan kaldırıp kaldırmadığına da bakılarak karar verilmektedir. Uyuşturucu maddelere karşı kişide iki tür bağımlılık gelişebilir. Bunlardan birisi "fiziksel bağımlılık" iken diğeri "psikolojik bağımlılık"tır. Fiziksel bağımlılık vücudun maddeye karşı yeni bir denge oluşturduğu ve alınmadığı zaman yoksunluk belirtileri görülen fizyolojik durum olarak tanımlanırken çoğu zaman psikolojik belirtiler bu duruma eşlik eder. Psikolojik bağımlılık ise maddeyi almaya devam etme arayışı ile kendini gösterir. Tütün, morfin ve kokain güçlü psikolojik bağımlılık yapan maddelerdendir (Uzbay, 1996, s. 16).

DSM-5'teki madde sınıflandırması şu şekildedir; alkol, kafein, esrar, halusinojenler (fensiklidin bu gruba dahil edilmiş ve grup kendi içinde fensiklidin ve diğer halusinojenler olarak ayrılmıştır), inhalanlar, opiyatlar, sedatif-hipnotik ve anksiyolitikler, stimülanlar (amfetamin, kokain ve diğer stimülanlar), nikotin ve diğer (ya da bilinmeyen maddeler) şeklindedir (Güleç, Köşger ve Eşsizoğlu, 2015, s. 450).

Tolerans: Bağımlıların hemen hepsi uyuşturucuya düşük dozlarda başlar fakat bu dozu kısa süre içinde artırmak zorunda kalırlar. Çünkü uyuşturucu kullanarak istedikleri etkiyi elde etmeleri için dozu artırmaktan başka seçenekleri yoktur. Artık kullanılan doz beklenen etkiyi sağlamamaktadır. Devamlı aynı miktarda kullanılan maddenin kişi üzerindeki etkisinin azalmasına "tolerans" denir. Kullanılan maddenin miktarı aynı olduğu halde aynı etkiyi göstermemeye bașlar ve rahatlama sağlanamaz. Kimi zaman yeterli madde alınmayışı nedeniyle bazı belirtiler görülebilir. Beklenen etkinin azalmasına karşın kişi genellikle kullandığı dozu artırma gereksinimi duyar. Yükselen dozla öyle bir noktaya gelinir ki, kişi bedeninin kaldıramayacağı miktarda madde kullanımı gerçekleştirir. Doz artışı beraberinde ağır zehirlenme ve ölüm ile sonuçlanabilir (Ögel, http://www.ogelk.net/Dosyadepo/tani.pdf).

Yoksunluk: Uyuşturucu maddelerin bir kısmının bir süre kullanımının ardından bırakıldığında yoksunluk belirtileri denilen birtakım rahatsızlıklar ortaya çıkar. Bunlar arasında bulantı, kusma, halsizlik, kas ve karın ağrısı, şiddetli uykusuzluk, bitkinlik, iştahsızlık sayılabilir. Uzun süre ve çok fazla madde kullanımından sonra azaltılmasına veya sonlandırılmasına bağlı olarak ortaya çıkan bir sendromdur. Ruhsal ve fiziksel belirtiler şeklinde kendini gösterir. Yoksunluk belirtileri, süresi ve şiddeti kullanılan maddenin cinsine göre değişir. Kişi bu belirtilerden kurtulmak için tekrar madde alma gereksinimi duyar. Ancak bu belirtiler yalnızca bedensel değildir. Bazı maddelerin kullanımı azaltıldığında veya kesildiğinde sadece ruhsal belirtilere neden olabilir. Bunlar arasında ise sıkıntı, mutsuzluk, depresyon, huzursuzluk, hiçbir şeyden zevk alamama olabilir. Ruhsal bağımlılık, tedavisi güç olan bir durumdur. Bağımlılık yapıcı maddeler belirtileri sebebiyle tekrar tekrar kullanılır ve kolaylıkla bırakılamazlar (Ögel, http://www.ogelk.net/Dosyadepo/tani.pdf).

\section{Madde Kullanımının Türkiye'deki Durumu}

Madde kullanımına yönelik ülkemize ait ilk geniş kapsamlı veri, 1962-1971 yılları arasında 10 yıl içinde Bakırköy Ruh ve Sinir Hastalıkları Hastanesi Toksikomani servisi kayıtlarına dayanır. 10 yıl süresince yatırılarak tedavi edilen 2878 olgunun \%26'sının opioid bağımlısı, \%24'ünün esrar bağımlısı, \%45'inin çoğul madde kullanıcısı olduğu tespit edilmiştir (Türkcan, 1998, s. 57).

2018 Türkiye Uyuşturucu Raporu'na göre ise; Türkiye genelinde 2016 y1lında toplam 81.222 uyuşturucu olayı görülmüşken, 2017 yılında \%45,87 artı̧̧ göstererek 118.482 olay meydana gelmiştir. Bu olaylarda bir önceki yıla göre $\% 48,92$ artışla 170.175 kişi uyuşturucu madde nedeniyle yakalanmıştır. Türkiye'de 2017 yılında gerçekleşen toplam 118.482 uyuşturucu olayının suç türlerine göre dağılımı incelendiğinde; 91.798 olayın $(\% 77,47)$ kullanma amaçlı uyuşturucu madde satın almak/kabul etmek/bulundurmak (TCK m.191), 23.424 olayın (\%19,77) uyuşturucu madde imal ve ticareti (TCK m.188), 3.136 olayın $(\% 2,65) 2313$ sayılı Uyuşturucu Maddelerin Murakabesi Hakkında Kanuna Muhalefet, 78 olayın $(\% 0,07)$ uyuşturucu veya uyarıcı madde kullanılmasını kolaylaştırma/özendirme (TCK m.190) ve 46 olayın (\%0,04) 3298 sayılı Uyuşturucu Maddeler ile İlgili Kanuna Muhalefet kapsamında gerçekleştiği görülmektedir. Türkiye'de 2017 yılında yakalanan toplam 170.175 şüphelinin suç türlerine göre dağıllımı incelendiğinde; 121.679 kişinin $(\% 71,50)$ kullanma amaçlı uyuşturucu madde satın almak/kabul etmek/bulundurmak (TCK m.191), 45.056 kişinin $(\% 26,48)$ uyuşturucu madde imal ve ticareti (TCK m.188), 3.301 kişinin $(\% 1,94) 2313$ sayılı Uyuşturucu Maddelerin Murakabesi Hakkında Kanuna Muhalefet, 92 kişinin $(\% 0,05)$ uyuşturucu veya uyarıcı madde kullanılmasını kolaylaştırma/özendirme 
(TCK m.190) ve 47 kişinin $(\% 0,03) 3298$ sayılı Uyuşturucu Maddeler İle İlgili Kanuna Muhalefet kapsamında yakalandığı görülmektedir.

Bununla birlikte Sağlık Bakanlığı Sağlık Hizmetleri Genel Müdürlügü’nün 2018 verilerine göre, 2017 yılında yatarak tedavi görenlerin cinsiyete göre dağılımları incelendiğinde \%95,67'sinin (11.129) erkek, \%4,33'ünün (504) kadın olduğu görülür (Türkiye Uyuşturucu Raporu, 2018, s. 42). Bu fark kadınların erkeklerden daha az madde kullandığına işaret edebileceği gibi, madde kullanan kadınların tedavi başvurusunun daha az olmasından kaynaklı da olabilir.

\section{Madde Kullanımında Aile İlişskilerinin Rolü}

Aile, TDK'ya göre "evlilik ve kan bağına dayanan, karı, koca, çocuklar, kardeşler arasındaki ilişkilerin oluşturduğu toplum içindeki en küçük birlik", "aynı soydan gelen veya aralarında akrabalık ilişkileri bulunan kimselerin tümü", "birlikte oturan hısım ve yakınların tümü" gibi anlamlara gelmektedir (TDK, 2019). İnsanın dünyaya geldiği ve hayatı öğrendiği bu yapıda güven ve huzur ortamını bulması gerekse de farklı nedenlerden dolayı her aile çocuğu için bu ortamını sağlayamamaktadır. Aile içinde yaşanan bazı olumsuz durumlar (çocuğun ihmal ve istismarı, ebeveyn çocuk iletişiminin bozuk olması, ailenin parçalanmış yapısı vb.) çocuğun evden soğumasına ve evi terk etmesine neden olabilmektedir. Çocuğun evden uzaklaşması demek onu bekleyen pek çok tehlikeye açık hale gelmesi anlamını taşımaktadır. Madde kullanımı da bu tehlikelerden biridir. Bircan ve Erden'e göre (2011) ise madde kullanım ve bağımlılığında risk faktörleri arasında; aile içerisinde sıcaklık ve şefkatin olmaması, ilişkilerin düşmanca yaşanması, diğer aile bireylerinde uyuşturucu kullanımının olması, anne-babaların aşırı otoriter ya da aşırı izin verici olması, anne-babanın reddedici ve ihmalkâr olması ön plana çıkmaktadır (Bircan ve Erden, 2011, s. 212). Yapılan bir araştırmada madde kullanan gençlerin aile yapıları tek ebeveynlilik, ebeveynlerden birinin vefatı ya da boşanmış anne baba açılarından incelenmiş olup sonuçta madde kullanan ergenlerin önemli bir kısmının boşanma, ölüm vb. nedenlerle tek ebeveynli ailelerde yetiştiği belirtilmektedir (Denton ve Kampfe, 1994, akt. Bircan ve Erden, 2011, s. 213).

Yaman'ın (2014) bir çalışmasında düşük gelir düzeyindeki ailelerin çocuklarındaki madde kullanım yaygınlığının yüksek gelir düzeyindeki ailelerin çocuklarından fazla olması bu ailelerde yaşanan bazı olumsuz süreçlere (örn. göç, süreğen bir hastalık) işaret etmektedir (Yaman, 2014, s. 101). Coşkun'un (2008) madde kullanan ergenler üzerinde yaptığı bir araştırmada ergenlerin aile özellikleri incelendiğinde parçalanmış aileye sahip ergenlerin oranının yüksek olması dikkati çekmekte ve araştırmaya katılan ergenlerin yarısının yoğun aile sorunları yaşadığı belirtilmektedir (Coşkun, 2008, s. 78). Lise son sınıfta okuyan gençler üzerinde yapılan bir alan araştırmasına göre ise gençlerin en çok; anne-baba tarafından eleştirilmek, sağlık durumları ile çok ilgilenilmesi, aşırı şekilde nasihat edilmesi, evde azarlanma, ebeveynlerinin kendisiyle ilgili her şeyi bilmek istemeleri, üstlerine çok düşülmesi gibi durumlardan şikâyet ettikleri saptanmıştır (Kulaksızoğlu, 2011, s. 43).

Madde kullandığı öğrenilen gençlerin ailelerinin tutum ve davranışları da ergenin nasıl bir yol izleyeceğini şekillendirmektedir. "Aile ortamında sorun çözme yöntemi olarak tercih edilen davranış kalıplarının, ergenlik dönemi problemlerine karşı anlayış ve sempati ile yaklaşmanın bağımlılığı önleyici etkileri olduğu gözlenmiştir”. Ancak madde kullanan gençlerin aktardığı şekliyle, çocuklarının bağımlı olduğunu öğrenen ebeveynlerin aşırı ilgi göstermesi ebeveyn ve genç arasındaki ilişkinin normale dönmesini zorlaştırmaktadır. Madde kullandığını öğrendikleri çocuklarına karşı ebeveynlerin aşırı ilgi göstermesi, gençler tarafından bunaltıcı olarak nitelendirilmektedir. İlginin artması gençler tarafından beklenen bir davranışken bu ilginin derhal bir değişme ve madde kullanımından kurtulma umuduna bağlanması gençleri sıkıntıya sokan bir durumdur (Yaman, 2014, s. 102).

\section{Madde Kullanımında Akran İlişkilerinin Rolü}

Ergenliğin bir geçiş dönemi olması sebebiyle getirmiş olduğu psikolojik ve biyolojik değişimlere alışma sürecinde ergenler, benzer durumları yaşayan akranları ile yakınlaşabildiğinden madde kullanan gençlerin akran gruplarıyla ilişkisini incelemek önemlidir.

"Grup içindeyken birey, kendine özgü bireysel özelliklerinden uzaklaşır. Böylece bireysel sorumluluk duygusunu kısmen kaybeder. Bu değişim kişinin tek başına iken yapmayacağı davranışları yapması sonucunu verir (örn. uyuşturucu kullanma, trafik kurallarına uymama...)" (Atabek, 2002, s. 126). 
Whitney madde kullanımı ve suçluluğun ailede yaşanan olumsuz durumlardan çok çevresel faktörlerden etkilendiğini ifade etmiştir (Akt. Özmen ve Kubanç, 2013, s. 365). Bu da gençlerde madde kullanımında arkadaş etkisinin ön planda olduğu anlamına gelmektedir. Türkiye Uyuşturucu ve Uyuşturucu Bağımlılığını İnceleme Merkezi'nin (TUBIM) 2008 yılı verilerine göre madde kullanıcıları maddeyi ilk sırada yabancılardan (\%42) ikinci sırada arkadaşlarından (\%38) temin etmektedir (TUBİM Raporu, 2009).

Benzer sorunlara sahip gençler (örn. boşanmış ebeveynler, okul başarısızlı̆̆ı, kültür çatışması) kendileri ile aynı sorunlara sahip kişilerle kendilerini daha iyi anlayacaklarını düşündükleri için yakınlaşırlar (Atabek, 2002, s. 125). Ortak kaderi paylaşan bu gençler beraber vakit geçirmeye başladıklarında artık kaderlerinin dışında pek çok ortak yönleri de oluşmaya başlamaktadır. Giyim tarzından konuşma tarzlarına takıldıkları mekânlardan sosyal paylaşım sitelerinde yaptıkları paylaşımlara pek çok alanda aralarında yeni bir dil ve yaşam biçimi ortaya çıkmaktadır (Yaman, 2014, s. 131). "Benzeşme" dönemi diye adlandırılan bu dönemde ergen arkadaşlarını taklit eder ve onlarla özdeşim kurar (Atabek, 2002, s. 122). Ayrıca madde kullanımı maddenin elde edilmesinin ve kullanılmasının kolay olduğu belirli yerlerde gerçekleşmektedir. Ergenlik döneminde kalabalık, denetimden ve kontrolden uzak ortamlarda bulunmanın madde kullanımı için risk oluşturduğu bilinmektedir. Bu koşulları sağlayan bazı sosyal aktivitelere katılım ergenin maddeyi tanımasına, kullanmasına ve maddeye istek duymasina neden olabilmekte, maddeyi bulmak ve tüketmek için uygun ortamı sağlayarak düzenli madde kullanımına yol açabilmektedir (Ögel, Ermağan, Eke ve Taner, 2007, s. 19).

Liseli gençlerle ilgili bir çalışmaya göre madde kullanan arkadaşı olanların, madde kullanma riski yaklaşık 6 kattır. Bununla birlikte erkeklerde polisle başı belaya giren ve hırsızlık yapan arkadaşı olma riski kızlara oranla daha fazla iken madde kullanan kızların antisosyal arkadaşlar bulma riski erkeklerden fazladır. (Ögel ve Aksoy, 2006, s. 111).

Madde kullanımına yol açan çevresel risk faktörleri üzerine yapılan çalışmalarda arkadaş özellikleri ve arkadaş etkisi ön plana çıkmaktadır. Araştırmalara göre ergenlerde madde kullanımına silah taşıma, suç işleme, başkasının malına zarar verme gibi şiddet içeren davranışların eşlik ettiği görülebilmektedir. Davranış bozukluğu tanısı konan ergenler, benzer davranışları gösteren ergenler ile arkadaş olurlar. Antisosyal arkadaşlar edinme, madde kullanan, polisle başı belaya giren, sık sık okuldan veya evden kaçan, disiplin cezaları alan bir arkadaşa sahip olma kullanım riskini artırmaktadır. Ergenlerde madde kullanımına sebep olan başka bir etken ise akran baskısı olabilir. Madde kullanan öğrencilerin madde kullanmayan öğrencilere göre şiddete eğilimli olma, suça karışma, madde kullanma, evden ve okuldan kaçma gibi özellikler gösteren arkadaş grubuna sahip olma olasıllğı daha yüksektir. Ergenlik döneminde ailesinden uzaklaşarak arkadaşlarına yakınlaşan ergenlerin, dahil olduğu grubun özellikleriyle özdeşleşerek benzer davranışlar sergilemesi ise beklenebilir bir durumdur. Arkadaş grubunda ergenin kendi inanç ve davranışlarının sosyal olarak desteklendiğini düşünmesi bağımlılık sürecinin başlamasında etken olabilir (Erdem, Eke, Ögel ve Taner, 2006, s. 111).

Sosyal, Ekonomik ve Kültürel Araştırmalar Merkezi'nin (SEKAM) 81 ilde, 179 kentsel ve 173 kırsal olmak üzere toplam 352 yerleşim biriminde, 15-28 yaş arası 5541 kişiyle uygulanan (\%50,9 kadın, \%49,1 erkek) Türkiye'de Gençlik ve Uyuşturucu Madde Sorunu çalışmasında arkadaş ortamlarına göre uyuşturucu madde kullanma durumu değerlendirildiğinde, arkadaş ilişkileri noktasında kendini bencil olarak nitelendiren gençlerin madde kullanma oranlarının daha yüksek olduğu görülmektedir $(\% 5,3)$. Buna karşılık dayanışmacı özelliğe sahip olan gençlerin uyuşturucu kullanma oranları en düşüktür $(\% 0,5)$. İkinci derecede madde kullanan gençler $(\% 4)$ ise rekabetçi olarak tanımlananlardır. Bununla birlikte arkadaş ortamında en çok ailevi meseleleri konuştuğunu ifade edenlerin \%2,1'i de uyuşturucu kullanmaktadır (SEKAM, 2015, s. 121).

Columbia Üniversitesinde 781 ergen kız ve annelerinin katılımıla gerçekleştirilen bir araştırma sonucuna göre de kızların alkol, reçeteli ilaçlar ve uçucu maddeleri kullanımı ile okul sonrası vakit geçirilen yerler, dış görünüşleri, depresyon, en yakın arkadaşın madde kullanımı, annenin içme davranışı, anne-kız etkileşimi ve madde kullanımına dair aile normları arasında ilişki bulunmuştur (Schinke, Fang ve Cole, 2008, s. 191). Latin Amerika'da toplam 1343 k1z ve erkek ortaokul ögrencisiyle yapılan dış görünüş, kültürleşme ve madde kötüye kullanımı arasındaki ilişkiyi araştıran bir çalışma sonucu ise dış görünüş algısının en yüksek risk olduğunu ortaya koymaktadır (Nieri, Kulis, 
Keith ve Hurdle, 2005, s. 617). Canada'da kız ve erkeklerden oluşan 148 kişilik bir grupla gerçekleştirilen ve akran baskısı, popülerlik ve uyum sağlama ile okul performansı, cinsel davranışları ve madde kullanımı arasındaki ilişkiyi inceleyen bir araştırma sonucuna baktığımızda ise akran baskısının madde kullanımı üzerinde önemli ölçüde etkin olduğunu görebiliriz (Santor, Messervey ve Kusumakar, 2000, s. 163).

Görüldüğü gibi ergenlik dönemindeki bir gencin madde kullanması durumuna etki eden pek çok faktör vardır. Ancak temel olarak bir sınıflandırma yapılırsa aile ilişkileri ve akran grubu ilişkileri ön sıralarda yer alabilir. En dikkat çeken noktalardan biri ise madde kullanımının bir şekilde sosyal çevre ile etkileşimde olmasıdır. Madde kullandığı için ailesinden ya da kullanmayan arkadaşları tarafından dışlanan ergen madde kullanımına daha yatkın hale gelebilmektedir. Dışlanmayla beraber gelebilen etiketlenme durumu ise kişinin hem ailesinden hem de arkadaşlarından ve toplumdan giderek daha da uzaklaşmasına neden olur. Madde kullanıcısı olarak damgalanmış birey maddeyi bırakma gücünü ve isteğini de kendinde bulmakta zorlanır. Bu durum ise madde kullanımı ve bırakamama durumunun kısır döngü halinde devam etmesine neden olur.

\section{YÖNTEM}

Araştırma Modeli: Bu araştırma, madde kullanan ya da önceden kullanmış olan ergenlerin ailelerinin sosyo-demografik özellikleri, aile işlevleri ve ailenin madde kullanımı davranışı üzerindeki rolü ile akran grupları ile ilişkileri ve arkadaşlarının madde kullanım davranışlarındaki rolünü incelemeye yönelik yarı yapılandırılmış görüşme formu doğrultusunda derinlemesine görüşme tekniğiyle bilgi alınarak yapılmış nitel bir çalışmadır.

Araştırmanın Evreni: Araştırmanın evreni İstanbul ilinde Çocuk ve Ergen Madde Bağımlılı̆̆ı Tedavi Eğitim ve Destek Merkezine (ÇEMATEM) tedavi için gelen ve madde bağımlılığı konusunda çalışmalar yürüten iki dernek Ayık Yaşamda Buluşalım Derneği ve Bağımsız Yaşam Derneği (AYBUDER, BAYDER) danışanları arasında 15-20 yaş aralığında ergenlik döneminde madde kullanan genç kızlardır.

Araştırmanın Sınırlııkları: Örneklem oluşturma noktasında madde kullanan genç kızların erkekler kadar ön planda olmaması sebebiyle genç kızlara ulaşmada güçlük çekilmiştir. Araştırma 15-20 yaş arası genç kızlarla sınırlı olduğu için görüşme yapmaya gönüllü olabilecek yetişkin kadınlar araştırmaya dahil edilememiş, bu durum görüşmeci sayısını kısıtlamıştır.

Araştırmanın Örneklemi: Araştırmanın örneklemini İstanbul'da yaşamakta olan ve ergenlik dönemlerinde madde kullanmış veya kullanmakta olan genç kızlar arasından, ÇEMATEM tedavi merkezine ve madde bağımlılığı noktasında gönüllü faaliyetler yürüten dernek merkezlerine gelen 15-20 yaş aralığındaki kızlar arasından rastgele seçilmiş 9 katılımcı oluşturmaktadır. Genç kızlara ek olarak görüşmeye gönüllü olan 3 yetişkin kadınla da mülakat yapılmış fakat çalışmanın yaş sınırlamasından dolayı bu katılımcılar çalışmaya dahil edilmemiştir. Araştırmanın nitel bir çalışma olması, madde kullanmış genç kızların erkeklere oranla fazla göz önünde olmaması, tedavi sürecinde Sivil Toplum Kuruluşları'ndan erkeklere oranla daha az destek alınması, çalışma için daha fazla katılımcı sayısına ulaşılmasını zorlaştıran nedenlerdir.

Veri Toplama Araçları: Bu araştırmada mülakat konusu çerçevesinde hazırlanan 33 soruluk (demografik bilgiler, madde kullanmadan önce, madde kullanma sürecinde ve maddeyi bırakma aşamasında aile ve akranlardan alınan tepkiler, destek ve yaklaşımlarla ilgili sorulardan oluşan) yarı yapılandırılmış görüşme formu doğrultusunda veri toplanmıştır.

Görüşme, küçük ölçekli eğitim araştırmalarında kullanılan en yaygın yöntemlerden biridir. Görüşme sırasında ayrıntılı yapı çalışmaya bırakılmıştır ve görüşülen kişinin ne konuşacağı, ne kadar söyleyeceği ve nasıl ifade edeceği konusunda özgürlük alanı geniştir. Yarı yapılandırılmış görüşme (semi-structured interview); yapılacak görüşme için genel bir çerçeve çizecek nitelikte ayrıntılı hazırlanan sorulardan oluşan ve görüşme esnasında akla gelen soruları sorabilme alternatifi sunan, genellikle resmi olmayan bir ortamda görüşerek gerçekleştirilen veri toplama tekniğidir. Yarı yapılandırılmış görüşme, küçük ölçekli araştırmalar için çok uygun bir tekniktir. Çok sayıda insanı içeren çalışmalar için uygun değildir ancak en çok mini çalışmalarda ve vaka çalışmalarında yardımcı olur. (Drever, 1995, s. 7; Longhurst, 2003, s. 143). 
Verilerin Toplanması: Araştırmada katılımcılarla yüz yüze görüşmek için birlikte kararlaştırılmış dış mekânlarda bir araya gelinmiş, ÇEMATEM tedavi merkezine ailesi ile birlikte gelen genç kızlarla ise ailelerinin de onayının alınmasıyla birlikte hastanenin bahçesinde görüşme yapılmıştır. Her katılımcı ile bir defa görüşülmüş ve ortalama 1 saatte görüşme gerçekleştirilmiştir. Yapılan tüm görüşmeler sonucunda veriler analiz edilerek bir araya getirilmiștir. Görüșmeye başlanmadan önce görüșmenin konusu ve amacı hakkında katılımcılara bilgi verilerek nasıl bir çalışmanın parçası olacakları konusu açıklı̆ga kavuşturulmuştur. Görüşme öncesinde hazırlanan yarı yapılandırılmış görüşme formunda yer alan sorular genç kızların madde kullanmadan önceki, madde kullanırken ve madde kullandıktan sonraki süreçlerine odaklanmaktadır. Yapılan görüşmelerden daha iyi ve daha net bilgiler alınabilmesi için katılımcıların rızası ve yaşı 18 altı olan katılımcılar için ailelerinin de onayı dâhilinde görüşmeler ses kaydına alınmıştır.

Verilerin Çözümlenmesi: Veriler, görüşmeler sırasında katılımcıların rızası ile alınan ses kayıtları deşifre edilerek yazıya geçirilmiştir. Deşifre araştırmacı tarafından yapılmış olup herhangi bir paket program kullanılmamıştır. Çözümleme sonucu elde edilen veriler bir araya getirilerek araştırma için bir bütünlük oluşturulmaya çalışılmış, görüşmelerde geçen konuşmalar katılımcıların ifade ettikleri şekilleriyle, kurdukları cümleler değiştirilmeden çalışmadaki yerini almıştır. Yapılan görüşmelerin analizi sırasında katılımcıların isimleri rastgele seçilen farklı harflerle ifade edilmiş ve yaşları parantez içinde belirtilerek kimlikleri gizli tutulmuştur.

\title{
BULGULAR
}

\section{Madde Kullanan Genç Kızların Aile İlişsilerinin Değerlendirilmesi}

Yapılan görüşmeler esnasında madde kullanan veya kullanmış olan genç kızların aileleri ile ilgili olarak en yaygın kanaatlerinin başında aile içi uygun olmayan iletişim yollarının varlığı ya da iletişimden kopuk bir aile ortamından geldiklerini düşünmeleridir. Bu konuyla ilgili verilen cevaplardan biri şu şekildedir:

\begin{abstract}
“-Arkadaş ve aile sürecinden sonra. Ailemle aram kötüydü zaten benim de kafamı dağıtmaya ihtiyacım vardı, sigarayı 6 yıldır kullanıyordum, sigarayı bıraktım bıraktı̆ım zaman annem inanmadı ayrıca bu yüzden dayak yedim, tekrar başladım, daha öncede dediğim gibi arkadaşlar sayesinde tanıştım, ailemle bayadır kötüydüm yani sevgilim ve arkadaşlarım bütün ailem, çevrem olmuştu, ben ailemi tanımıyordum o zamanlar. Tanışmam böyle oldu. ” (H., 20)
\end{abstract}

Genç kızın bir birey olarak aile içinde değer ve saygı görmeyişi, anne-baba ile derdini anlatacak ve sırını paylaşacak düzeyde bir ilişki ve yakınlığın olmaması; genç kızların madde kullanımına sebebiyet vermektedir. 3 yıldır bağımlı olan B., yapılan görüşmede ailesinin kendisini sıkması ve ailesinde kız kardeşinden başka sırrını paylaşabileceği birinin olmaması üzerine madde kullanmaya başladığını ifade etmiştir:

“-Annemle biraz sıkttğı için fazla yani şey değilim hatta bazen sevmiyorum bazen çok seviyorum ama çok sıktı̆̆ iç̧in fazla iyi değilim, babamla zaten babamın yüzünü fazla göremiyorum işte geceleri üçte filan geliyor sabahta çılkıor fazla iletişim olmuyor, kız kardeşime bir tek her şeyi dökebiliyorum, ablamda evlendiği için zaten evlenmeden önce de zaten görüşmüyorduk hani yani öyle şey konuşmuyorduk o şekilde. Beni ailem sıkıyor dedim ölemiyorum madem dedim sigara mı içsem ne yapsam dedim arkadaşlarıma dedim ki ben artık hayattan nefret ediyorum, evden kaçacağım dedim onlarda kaçma gel ben seni rahatlatacak bir şey vereyim dedi kaç para dedim 15 lira dedi adı ne dedim korex dediler. (B., 19)

B.'nin de belirttiği üzere evden kaçma isteği, madde kullanan genç kızların, ailede yaşadıkları sorunlara karşı bir çözüm yolu olarak karşımıza çıkmaktadır. Evden kaçma ve aileden uzaklaşma isteği, genç kızların yaşadıkları çatışmalardan ve problemlerden uzak kalmak istemeleri şeklinde değerlendirilebilir. Belirtilen bu durum madde kullanan diğer genç kızlar tarafindan da dile getirilen bir durumdur. Nitekim yapılan görüşmeler esnasında E. madde kullanımından dolayı ailesini suçlamakta ve çözüm yolu olarak evden kaçtığını belirtmektedir:

“-Ailemin tepkisi beni ilk başta üzdü ama sonra onları suçladım sizin yüzünüzden ben bu durumdayım diye sonra evden kaçmaya başladım hiç eve gitmiyordum." (E., 17) 
Ailede yaşanan bu çatışmalar zamanla daha da ciddi sorunlara yol açabilmekte, özellikle madde kullanan genç kızların ailesi tarafindan şiddet görmesi ile sonuçlanabilmektedir. Madde kullanan genç kızların ailelerinde yaşadıkları bir başka önemli sorun ise aile içi ihmal ve istismar olgusunun varlı̆̆ıdır. Ailede yaşanılan ihmal ve istismar ailede önemli işlevleri bozma eğilimindedir. B. çocukluğunda ailesinden gördüğü ağır şiddeti madde kullanımına giden bir vesile olarak görmektedir ve kendisine iyi davranıldığı takdirde madde kullanmaya başlamayacağını belirtmiştir:

“-En çok bir de şey etkiledi mesela ailem küçükken her gün dövüyordu. Ben bir öğün yemek yiyordum, dört öğ̈̈n dayak yiyordum, beni gidiyordu tuvalete kitliyordu, köpek misali önüme bir tas koyuyordu al köpek diyordu ye diyordu bu yemekten aynı şekilde. Benim buna başlamamin sebebi kesinlikle ailem yani, arkadaşlarım var tamam var ama ailem bana iyi davransa size yemin ediyorum minnacık, azıcık bana iyi davransa Kur'an çarpsin ben bunu birakırdım zaten, ben hiç başlamazdım bile." (B., 19)

Ailede şiddet gören, evde huzur bulamayan gençler zamanla yalnızlaşmaya başlamaktadır ve kendisini ifade edebileceği, kendisi ile özdeşim kurabileceği bir akran grubuna yönelmektedir. Madde kullanımında akran grubunun etkisi yadsınamayacak derece önemli iken B. madde kullanımında daha çok ailesinin etkisinin olduğunu söylemektedir. A.'nın de anlattıkları ile madde kullanan genç kızların yaşadıklarının bir istisna olmadığı, bağımlı kızların ailelerinde şiddetin var olan bir gerçekliğe karşılık geldiği düşünülmektedir:

“-Yani çok süreç var. Bir kere eski sevgilimden ayrıldım. Ondan sonra annem falan babamla evdeki herkesle çok kötüydü aram. Biraz asi bir insanım. Onun dışında öyle yani.

-Annenle babanın boşanma sürecinden önce miydi bu?

-Hayır sonra ama babamla falan. Babam benim şiddet uyguluyor o yüzden mesela çok sıkıntı çektiğim için.

-Yani hayatında şu olsaydı kullanmazdım dediğin bir şey var mı?

-Hayatımda babam olmasaydı kullanmazdım.” (A., 17)

Aile içi şiddetin genç kızlarda ne gibi sonuçlar doğurabileceği hakkında A.'nın anlattıkları ile şiddetin sonuçları daha net bir şekilde anlaşılabilmektedir. A. babasının kendisine uyguladığı şiddet karşısında, mutluluğu uyuşturucu madde kullanmakta arayan bir genç kız olarak karşımıza çıkmaktadır.

Ebeveyn kaybı, boşanma gibi çeşitli sebeplerden dolayı anne-babanın birlikte yaşayamaması, çocukların akraba yanında veya yurtta kalması aile yapısını değiştiren bir durum olarak karşımıza çıkmaktadır. Mevcut aile yapısının değişmesi, aile üyelerine düşen rol ve sorumlulukta bir karmaşa oluşmasına sebebiyet vermektedir. Ailede yaşanan bu uyum problemleri karşısında genç kızların maddeyi denemesi ve kullanması beklenebilen bir durumdur. Aslında değişen bu aile yapısı karşısında madde kullanımı, genç kızların yaşadıkları ruhsal travmaya ve depresyona verdikleri bir yanıt olarak değerlendirilebilir. M., çeşitli sebeplerden dolayı baba ve abisinin cezaevine girdiği parçalanmış bir aileden gelmektedir:

“-Ailevi sorunlarım oldu ondan sonra kullanmaya başladım

-Biraz açabilir misin?

-Abim, babam cezaevine girdi öyle kullandim." (M., 16)

Aile yapısında; babanın ve abinin cezaevine girmesiyle meydana gelen bu değişim diğer aile üyelerinin rollerinin değişmesi ve artması anlamına gelmektedir. Anne ve babanın çocuklarını birlikte yetiştirememesi, annenin bu durum karşısında babanın rollerini de üzerine almasını gerektirmektedir. Annenin artan bu sorumluluklar sonucu çocukları ile yeterli bir şekilde ilişki kuramaması, çocuklarına vakit ayıramaması genç kızlarda maddenin denenmesine ve sürekli kullanımına neden olabilir.

Ailesinde alkol ve madde bağımlılığı öyküsü olan ergenlerde madde kullanım riski artmaktadır (Ögel ve Aksoy, 2006). Aile üyelerinin madde kullanımı ile aile zor bir değişim sürecine girmektedir. Bu değişim sürecinde ailede madde kullanan üyenin varlı̆̆ı, ergenlerin madde kullanımını yaşayarak 
ögrenebilecekleri bir ortama sahip olmalarına neden olmaktadır. B., ailesinin karşısında alkol kullanan bağımlı bir babaya sahip olmasının madde kullanımındaki etkisini şu şekilde belirtmektedir:

“-Babamdan kopuğum tamamen ya içiyor bizim karşımızda, her gün bir insan niye içer, geliyor içiyor, ya sen bunu niye içiyorsun tamam içiyorsun dışarıda tamam sabah geliyorsun, ben senin zaten yüzünü görmüyorum ama sen bunu getirip benim karşımda içersen ben bırak esrarı, bırak maddeyi, bırak içkiyi ben bunu yapmasam bile yaparım yani niye bunu yapıyorsun." (B., 19)

Aile içi ilişkilerin babanın alkol kullanımı ile yeniden tanımlandığı bu süreçte babanın rol ve sorumlulukta kayıplar yaşaması, görüldüğü gibi genç kızlarda kalıcı sorunlara yol açabilmektedir. Ailede babanın varla yok arasında olması, babanın çocukları ile duygusal olarak uzaklaşması çocukların gelişimleri üzerinde olumsuz bir etki meydana getirmektedir.

Bağımlı genç kızların maddeyi denemesinde, madde kullanan aile üyesinin varlığı yadsınamamaktadır. Örnek bir rol-model kardeşe sahip olamama, kardeşin ailede varla yok arasında olması ve kardeşin madde kullanması genç kızları madde kullanımı ile karşı karşıya getirebilmektedir. Bağımlı bir abisi olan O., ilk madde deneyimini abisini tiner kullanırken görmesine bağlamaktadır. Bağımlı bir abinin maddeyi kardeşinin göreceği bir şekilde kullanması O.'nun tinere karşı bir merak duygusu oluşturmasına neden olmuştur.

“-Illk tiner. 11 yaşındaydım, ilk evde kullandım, nasıl kullanıldığını biliyordum, benim abim de madde bağımlısı, bu nasıl içiyor bende bir bakayım dedim o yüzden başladım. Tektim. Ben söyleyene kadar kimse beni aylkamad,, çözemedi, ben söyledim anneme. 13-14 yaşlarında söyledim, o zamana kadar anlamadılar." (O., 17)

Ergenlik döneminde genç kızın aile içinde madde kullanımına tanık olması, yaşanan travmanın boyutlarını artırmaktadır. Nitekim E. madde kullanmasının kardeşinde oluşturduğu özen ve merak duygusunu şu şekilde ifade etmektedir;

“-Kardeşim (14) benden özenmeye başladı o da yavaş yavaş benden gördüğ̈̈ için özenmeye başladı yani satan çocukların yanına falan gidiyor özenmeye başladı şu an da içmiyor ama özeniyor." (E., 17)

Madde kullanan bireyin rol model alınması, zamanla ergenlerde maddeye karşı merak ve özenti duygusunu ön plana çıkarmaktadır. Esra'nın kardeşinin şu anda madde kullanmaya başlamamış olması mevcut tehlikeleri ortadan kaldıran bir durum değildir. Madde kullanmış genç kızların ailelerinde karşılaşılan diğer bir sorun ise, ailenin düşük sosyo-ekonomik düzeye sahip olmasıdır. Gelirlerinin düşük olmasının madde kullanımında etkisi olduğunu düşünen O. şunları ifade etmektedir:

“-Hayatımı, ailemi yani hayatımın düzeni, birliği, hani sıkıntı yaşamadan hani ev ortamı sıkıntılı olmadan, hani rahat yaşayabileceğim bir ortam olmasını isterdim. Annem-babam aynı kişiler olsaydl, özellikle annem hani rahat bir ortamımı olsaydl, gelirimiz iyi olsaydı onlar yeterdi zaten." (O., 17)

Yoksulluk ve yoksulluğun beraberinde getirdiği yetersiz yaşam koşulları ile ailelerinde yeterince sevgi ve destek görmeyen genç kızların madde kullanımı gibi riskli davranışlara yönelmeleri beklenen bir durumdur. Nitekim maddi kaynakları yetersiz olması gençlerin toplumda eğitim, sağlık, sosyo-kültürel vb. faaliyetlerden yeterince faydalanamamalarına sebep olmaktadır. Yaşanan bu zor şartlar altında genç kızların kendilerini toplumda var etme çabası madde kullanımı ile sonuçlanabilmektedir.

Ebeveynlerin uygun olmayan çocuk yetiştirme tutumları, çocukların psiko-sosyal gelişimine ciddi ölçüde zarar verebilmektedir. Ebeveynlerin aşırı izin verici, ilgisiz ve reddedici davranışlar sergilemesinin genç kızlarda madde bağımlılığına sebep olduğu söylenebilir. Ailesi tarafından rahat ve serbest bırakıldığını düşünen Z. ailesinin madde kullandığını öğrendiğinde bu davranışlarının devam ettiğini belirtmiştir:

“-Yaptıklarımın bir kısmında ailemi suçluyorum, niye suçluyorum bana engel olabilirlerdi hani inanıyorum buna, onlar ögrendiğinde bile bıraktım dediğimde inanmışlardı bana, ben asla çocuğuma inanmam kötü bir alışkanlı̆̆ olduğunda onu bıraktım dediğinde. Biraz serbest birakldım ben." (Z., 16) 
Çocuklarının nerede, kiminle ve nasıl vakit geçirecekleri konusunda aktif bir denetim ve kontrole sahip olmayan ebeveynlerin çocukları anlık doyumlar ile yetinmeyi öğrenmektedir. Anne ve babanın çocuk yetiştirme konusundaki pasif tutumları genç kızları madde kullanımı karşısında daha korumasız kılmaktadır. Buna karşın ebeveynlerin çocuklarına karşı baskıcı bir karaktere sahip olması çocuklarda özgüven yetersizliğine ve mutsuzluğa sebep olabilir. Özgüven yetersizliğini ve sorunlarını madde kullanımı ile aştığını düşünen genç kızların madde kullanımını sürdürmesi beklenen bir durumdur. $\mathrm{Bu}$ konuyla ilgili bir katılımcının görüşleri şu şekildedir:

“-Tek istediğim işte ailem niye böyle yaptı sadece ben onu kullanırken düşündügüm şsey buydu ailem bana kötü davranmasın beni sımmasın ben bunu yapmayayım keşke böyle olmasa da şöyle olsa keşke fakir olmasak da şöyle olsa aklinda bir sürü şey geçiyor diyorsun evlensem de kurtulsam mi ya da mesela evlenmeyeyim evlilikten korkuyorum ama bu şeyi kullandiktan sonra belki her şey düzelir diyorsun ve o psikoloji altında kaldığın için devam ediyorsun bu şekilde ve etrafinda kullanan çok kişi oluğu zaman çok güzel geliyor atıyorsun ve kendini kötü hissediyorsun kullanırken güzel geliyor ama sonra kötü hissediyorsun arkadaşlarımın hemen hemen hepsi kullandı bende tabi çok iyi bir şey zannettim aile baskısı olduğu için üzerimde o kadar siknldım o kadar patladım ki anlatamam yani kendimden bile nefret ettiğim zamanlar oldu bu nasıl kız dediğim zamanlar oldu aynaya bakıp dört saat ağladı̆̆ım günleri hatırlyyorum, oldu, neden böyle psikolojik sorunlarım oldu atlatmaya çalıștım ama olmadı yani düzelmedi baktım gördüm düzelmedi, düzelmeyince ben bu maddeyi kullanayım düzelirim filan zannettim." (B., 19)

B.'nin de belirtmiş olduğu gibi baskıcı ve otoriter ebeveyn tutumları genç kızları sadece madde kullanmaya itmekle kalmamakta, geleceğe karşı düşüncelerini ve isteklerini olumsuz yönde etkileyerek geleceğe korkuyla yaklaşmalarına sebep olabilmektedir.

Bağımlılık sadece bireyi etkileyen bir beyin hastalığı değildir, tüm aile üyelerini etkileyen bir hastalık olarak karşımıza çıkmaktadır. Çocuğunun madde kullandığını öğrenmesi aile için bir kriz durumudur. Aileler çocuklarının bağımlı olduklarını öğrendiklerinde çeşitli sıkıntılar yaşarlar. Bu sıkıntılar şu şekilde özetlenebilir; hayal kırıklı̆̆ı, suçluluk, inkâr, ümitsizlik, şaşkınlık, öfke, utanç, korku, beklenti, çocuğa odaklı bir yaşam sürmek (Ögel ve Tamar, ty, s. 16-17). Üç aydır madde kullanmayan Ayşe, annesinin madde kullandığını öğrendikten sonraki tutumunu şu şekilde aktarmıştır:

“-Bir tek annem biliyor o da çok iyi davranıyor yani bu süreçte hep yanımda oluyor. Her şeyime geliyor.” (A., 17)

Görüldüğü gibi aileler çocuklarının madde kullandığını öğrendiğinde, eskiye nazaran aile ilişkileri olumlu yönde bir değişim gösterebilir. Ailenin bu süreçte çocuklarına karşı takındığ gösterdiği davranışlar genç kızların yaşadıkları bu süreci daha zararsız bir şekilde atlatmalarına yardımcı olabilmektedir:

“-Ailem o kadar iyi davrandı ki sirdaşım gibi oldular, normalde bu kadar iyi değildi ama madde kullandığımı öğrenince çok içli dışlı olduk yani daha çok kenetlediler.

-Ailenin davranışları seni nasıl etkiledi?

-Çok iyi etkiledi yaa o an ailemin bana daha çok değer verdiğini anladım.” (M., 16)

Ailenin bu süreçte çocuklarının yanında olmalarına, destek vermelerine rağmen onlara karşı güvensizlik duygusunun oluşması da ailenin verdiği tepkiler arasında yer alabilir. ÇEMATEM'de üç aydır tedavi gören S. ise ailesinin kendisine karşı bazı güvensizliklerinin olmasına karşı bu süreçte destek olduklarını şu şekilde ifade etmiştir:

“-Annem ögrendi ilk önce, 5 ay önce, söz verdim içmeyeceğim diye, yine içtim sonra beni buraya getirdi. Babamda arkadaş gibi konuştu.

-Peki ailenin bu davranışları seni nasıl etkiledi?

-Olumlu yönde etkiledi.

-Peki o zaman mi birakmaya karar verdin? 
-Evet. Üç aydır tedavi görüyorum. ÇEMATEM'e annem, babamla gelip gidiyorum. ” (S., 15)

Nitekim S.'nin de ailesinde olduğu gibi, ailelerin çocuklarına karşı duyduğu güvensizlik ile bu süreçte onlara karşı destekleri birlikte yürümektedir. B. ise ailesi ile olan ilişkisi nedeniyle maddeyi bir sefer denediğini söylemiş, bağımlı olduğunu saklamıştır. Ailesine maddeyi denediğini söyleyen B. yaşadığı süreci şu şekilde anlatmaktadır;

“-Ben anneme madde kullanmiyorum ama dedim bir kere tadına bakmak için yaptım dedim o sadece bir kere içtiğimi biliyor o kadar içtiğimi bilse zaten beni yani evlatllktan reddeder. Ĕ̈er hap falan kullanırsan ĕger dedi işte beni sen benim kızım olamazsın dedi, ondan sonra seni evlatlkktan reddederim dedi. Sadece annem ögrendi, annem babama söyledi sonra işte şu an kullanmıyor biliyorlar sadece bir kere içtiğimi biliyorlar. Nasıl davrandılar, dediler ki hiç yani sanki normal bir hap içmişim gibi hiçbir şey de demediler valla sadece dediler ki bir daha yaptığını görmeyeyim yoksa işte seni evlatlktan reddederim işte sen dedi benim kızım olamazsın şöyle böyle falan filan. Zaten anneme söyleyecektim ama bana evlatlkktan reddederim dediği için söyleyemedim." (B., 19)

Çocuklarının madde kullanımı karşısında ebeveynlerin çocuklarına karşı "seni evlatlıktan reddederim, sen benim kızım olamazsın" gibi çocuğu reddedici söylemler ailenin gerçeklerden habersiz bir şekilde hayatlarını sürmelerine sebep olmaktadır. Görüldüğü gibi B. bu süreçte ailesine karşı duyduğu korku nedeni ile madde kullandığını bir kere ile sınırlandırdığını ifade etmiştir. Bununla birlikte bazı aileler çocuklarının madde kullandığını öğrendiğinde bu durumu anlayışla karşılayarak tepkilerini en aza indirmeye çalışırlar. Ebeveynlerin gösterdiği bu tepkiler çocuklarının madde kullanım davranışını meşrulaştırmaya çalıştıkları ya da çocuklarının madde kullanımına devam etmesi istedikleri anlamına gelmemektedir.

H. ise ailesine madde kullandığını söylemeden önce annesinin bir şeyler sezdiğini şu şekilde aktarmıştır:

“-Babam şok oldu hatta kalp krizleri böyle başladl, kalbini tutarak yatmalar, nefesinin darlanması. Annem de tahmin ediyordu zaten bir şseyler olduğunu ama böyle olduğunu bilmiyordu, çünkü eve birkaç kere maddeli geldim böyle evde kullandığım zamanlara bir şey olmuyordu çünkü gramajını kendim ayarllyordum kafamı ona göre yaşıyordum ufak bir uçkunluk versin tamam bana yetiyordu ama dışarıda kullandı̆̆ım zaman bedava nasıl olsa bir gram bir buçuk gram yarım fişek falan hepsini kullaniyordum, eve geldiğimde kendimde olmuyordum zaten yüzüm gözüm mosmordu çok kaşınıyordum, o şekildeydi. Ailemin tepkisi de ilk baş̧ta çok kizdılar inanamadılar ama ondan sonra arkamda durdular." (H., 20)

$\mathrm{Bu}$ süreçte ailelerin yaşadıkları tepkilerden bir diğeri de çocuklarının madde kullanımını inkâr etmeleri olarak karşımıza çıkmaktadır. Ailenin yaşadıkları bu şok karşısında durumu inkâr etmeleri, yaşadıkları hayal kırıklıklarını örtbas etmeye çalışmaları olarak değerlendirilebilir. Zamanla aileler yaşanılan bu süreci kabullenebilmekte ve çocuklarına destek olmaya çalışmaktadırlar.

“-Öğrendiklerinde çok kötü oldular beni eve kilitlediler ama ben evdeyken bile kendime maddeyi buldum yollarla. Sigara paketini aşă̆ı attım baba paketim aşă̆ düşı̈̈ dedim sonra arkadaşım içine madde koyup eve getirdi paketi sonra onu içerken annem yakaladı daha sonra beni hastaneye yaturdilar zaten." (P., 17)

Görüldüğü gibi çocuklarının madde kullandığı gerçeğiyle yüzleşen aileler, bu durum karşısında çocuklarını eve hapsederek sorunu bertaraf edebilecekleri düşünebilmektedirler. Ailenin kızlarını bulundukları çevreden uzak tutarak başka bir şehre göndermeye çalışması, kızlarının kendisine maddeyi hatırlatacak yaşam deneyimlerinden uzak kalmasını istedikleri şeklinde değerlendirilebilir. Görüldüğü gibi ailelerin bu süreçte verdikleri tepkiler aile içi ilişkilere, ailenin birbirlerine duydukları sevgi ve güven değerleri ile değişkenlik gösterebilmektedir.

Bağımlılık tedavisindeki başarı bireye, aileye ve tedavi yöntemine göre değişmektedir. Tedavide başarıyı artıran faktörlerden en önemlisi kişinin istekli ve kararlı olmasıdır. Bağımlı kendini değiştirmeye çalışırken, ailesi ise değişimleri kabul edici bir tutum sergilemelidir. $\mathrm{Bu}$ noktada ailenin desteği önemlidir (Ögel, T.Y). Madde kullanımını bırakan A. tedavi süresince ailesinin desteğini şu şekilde ifade etmektedir: 


\section{“-Çok zorlandım ilk başta ama sonradan tabi ya annem yanımda hep olduğu için hiç sıkıntı çekmedim.” (A., 17)}

Tedavi sonrasında aile desteğinin devam etmesi genç kızların madde kullanımına devam etmesi yönünde engelleyici bir tutum oluşturabilmektedir. $\mathrm{H}$. ise bu süreçte ailesinin kendisini sürekli kontrol ettiğini ve bu durum karşısında ailesinin bunları yapmak zorunda olduklarını belirtmiştir:

“-Ailem bırakma sürecinde çok sıkı davrandı aşırı sıkı o kadar bunalttılar ki sanki ben tekrar başlayacaktım o derece oldum yani öyle diyeyim, ablamda kallyordum zaten benim manevi bir ablam vardı benim psikoloğumun tanıştırdı̆̆ o abla sayesinde ben biraktım mesela, babam bir bakımdan ama annem her attı̆̆ım adımı affedersin iç çamaşırıma bile baktığını biliyorum ben, kullanıyor musun kullanmiyor musun diye yani o dereceydik ama yine de iyiydi bu yaptıkları şimdi düşününce yani yapmak zorundalarmış bunları." (H., 20)

\section{Madde Kullanan Genç Kızların Akran İlişkilerinin Değerlendirilmesi}

Akran baskısı; kişinin dâhil olduğu akran grubunda herhangi bir aktiviteyi, etkinliği yerine getirmek üzere cesaretlendirilmesidir. Bu baskı veya cesaretlendirme nedeniyle genç grupta kalabilmek için kendinden beklenen riskli davranış1 yerine getirebilir (Yörükoğlu, 1996; akt. Esen, 2003, s. 176).

Araştırma sürecinde görüşme yapılan genç kızların büyük çoğunluğu madde kullanımına arkadaş ortamında ve arkadaşlarının "cesaretlendirme veya baskıları" yüzünden başladıklarını belirtmektedirler. Ailesinden bağımsızlığını kazanmaya çalışan ergen, güven ihtiyacını tatmin edebileceği başka yapılara yönelmektedir. Akran grupları bunların başında gelir. Ergen için bir akran grubuna dahil olmak ergenlik döneminin en önemli gelişmesidir. Ergenlikte bir akran grubuna dahil olabilmek demek aileye olan bağlılığın azalması demektir. Gençler için bu özgürlüğe kavuşabilmek, akran grubunca kabul edilmek demek; grup üyelerinin yaptığı ve onun da yapmasını sözlü ya da sözlü olmayan yollarla ifade ettiği her şeyi yapmak anlamına gelebilmektedir. Akran baskısı bu süreçte devreye girmektedir. Foster ve Spencer'ın (2013) yaptığı bir araştırma, gençlerde uyuşturucu ve alkolün arkadaşlarıyla paylaşım noktasında nispeten ucuz bir eğlence sağladığını ve neoliberal şehirlerin bireysel ve yalıtıcı sınırlarında elde edilmesi zor olan samimiyet firsatları sunduğunu göstermektedir. Araştırma, genç uyuşturucu kullanıcılarının uyuşturucu ve alkole olan kabul edilebilir ve kabul edilemez ilişkiler arasında nasıl sınırlar çizdiğini, madde kullanımının ileri düzeyde kullanıcılara ait önemli bir aidiyet duygusunu ifade ettiğini göstermektedir. Bu "sınır çalışması" sayesinde, esrar içtikleri ve alkol içtikleri insanlarla paylaştı̆̆ bağları sağlamlaştırmaktadırlar.

Araştırmaya konu olan genç kızlar için de durum bundan farklı olmamakla birlikte, büyük çoğunluğunun ailesiyle yaşadığı problemlerden kaçmak için akran gruplarına dâhil olduklarını söylemek yanlış olmayacaktır. Gençlerin isteklerinin ailede dinlenmemesi ya da önemsenmemesi genelde ebeveynlerin otorite sağlama yöntemlerinin bir sonucu olabilmektedir. İstek ve ihtiyaçlarının ailede karşıllk bulmaması genç kıza kendini değersiz, boş, önemsenmeyen, varlığı bile bir yük olarak görülen, hayatta önemli bir rolü olmayan biriymiş gibi hissettirebilmekte hatta genç kızın ailesine karşı sert tutumlar sergilemesine neden olabilmektedir. Genç kız bu durumun vermiş olduğu baskı ile kendisini ailesinden mahrum bırakmak isteyerek aileden kopup akran gruplarına yönelebilmektedir. Genç kızın arkadaşlarını ailesine tercih etmesinde aile içi iletişimin büyük etkisi olduğunu vurgulamak doğru olacaktır.

"Maddeyi ilk kullandığında yanında kimler vardı?” sorusu görüşmecilere sorulmuş ve alınan cevaplar değerlendirilmiştir. Değerlendirmeler sonucu görüşme yapılan 10 genç kızdan sadece ikisi ilk deneyimde yalnız olduklarını belirtmişlerdir. Bu da gerek ilk madde kullanım deneyimi gerek bağımlılık sürecinde akran grubunun önemini ortaya net bir şekilde koymaktadır.

“-Açık öğretimden meslek liselerine eğitim var ona gidiyordum, arkadaşımın sevgilisi sayesinde başladım bundan iki yıl önce neredeyse. Arkadaşımın sevgilisinin evine gitmiştik orada tanıştım, bunlar masada içiyorlardı bende onları ilk reddettim sonra onlar salondan kalkıp gittiklerinde ben de kullanmaya çalıştım bilmediğim halde daha sonradan olaylar olaylar başlamış oldum." (H., 20)

Madde kullanan akran gruplarıyla bir şekilde temasa geçen ve madde kullanmaya başlayan genç kızlar için süreci saklamak çok uzun sürmeyebilmektedir. Gerek sık sık evden dışarıda vakit geçirmeye 
başlamalar ya da maddeyi temin edebilmek için başvurulan yollarla genç kız kendini ele verebilmektedir. Durumdan haberi olmayan ve madde kullanmayan arkadaşların durumu öğrenmesi halinde madde kullanan genç kıza yönelik tutum ve tavırları sertleşebilmektedir. Yapılan görüşmelerde madde kullanmayan arkadaşları olan genç kızların durumu öğrendiklerinde kendileriyle görüşmeyi bıraktıklarını ifade edenlerde olmuştur. Genel olarak madde kullanmayan arkadaşlar madde kullanım sürecinde genç kıza en fazla öğüt verebilmekte, etkilemek anlamında çok destek olamamaktadır. Madde kullanmayan arkadaşlar kendilerinden mahrum ederek ya da kendilerini madde kullanım riskinden koruyabilmek için aralarına mesafe koydukları genç kızlara ancak tedavi sürecinde daha iyi destek olabilmektedirler.

Görüşmecilere sorulan bir diğer soru olan "Arkadaşların madde kullandığını öğrendiğinde sana nasıl davrandılar?" sorusunu bir görüşmeci bu şekilde yanıtlamaktadır:

“-Dışladılar tabii ister istemez. Gerçek dost dediğim insanlar üzüldüler hani yapma etme dediler hiç gerek yok falan dediler ama tabii hani böyle kötü dost olanlarda zaten şey yapıyorlar ailen kötü aran da kötü iç ne olacak yani zaten onlar yüzünden bu durumda oldum.” (E., 17)

Akran baskısının madde kullanımı kadar bırakma sürecinde de etkili olduğunu "Arkadaşların bırakma sürecinde sana karşı nasıl davrandılar?" sorusuna verilen bu cevap ortaya koymaktadır:

“-Tabii iyi olanlar sevindiler çok sevindiler kötü olanlarda niye bırakyyorsun gel beraber içelim dediler tekrar düşürmeye çalıştılar ama kanmadım.” (E., 17)

Birçok gereksinimini akran grubundan karşılamaya başlayan ergen artık akran grubunun kontrolüne çok rahat girebilir. Akran grubunun kontrolüne giren onların istediklerini yapmakta tereddüt etmez ve akran grubu gibi hareket etmeye başlar (Esen, 2003, s. 169).

Özellikle benlik saygısı düşük ergenlerin kendilerini çevreye karşı olumlu ve yeterli gösterme ve grup içinde statü kazanma çabaları, grubun kontrolüne girmeleri ve gruptakilerin istediği şekilde davranmaya başlamalarıyla sonuçlanabilmektedir. Görüşmeler sırasında; "arkadaş ortamına ayak uydurabilmek, onlar gibi olabilmek ne hissettiklerini anlayabilmek" üzere ilk deneyimin ve ardından bağımlılığın başlamasıyla sıkça karşılaşılmıştır.

“-Ortamlar arkadaş̧ çevresi falan derken iyice dağıttım kendimi. Sonra okuldan devamsızlıktan dolayı atıldım kavga ettim.” (E., 17)

Madde kullanım sürecinde arkadaşlarını suçlayan, arkadaşlarına "hayır" diyemediği için bağımlı olduğunu dile getiren bir katılımcı sözlerini şöyle sürdürmektedir;

“-Yaa arkadaş etkisi, onları değiştirmek isterdim, hayır demek isterdim.” (S., 15)

Madde kullanımıyla ilgili yapılan çalışmalarda çoğunlukla; akran etkisi, ego zayıflığı, benlik saygısının yoksunluğu, kişilik sorunları, kullanım alanları, uyum sorunları, bozuk çevre, stres faktörleri öne çıkmaktadır (Gökler ve Koçak, 2008).

Bunlardan farklı olarak gençler arasında kullanma sebeplerinden biri de "merak" duygusu olarak ön plana çıkmaktadır. Gençler arasında sadece merak ettiği için madde kullanımına başladığını belirtenler olmuştur. Bununla ilgili bir gencin ifadesi şu şekildedir:

“-Valla bir beklentim yoktu. Merak ettim denedim sadece. O (K'nın erkek arkadaşı) kullaniyordu. Bende onu seviyordum ve iletişim kurabilmek için. Yani aslinda merak sadece. Deneme merak. Ne hissettiğini anlamak. Ne hissedeceğini görmek. Yani bir beklenti çok kötüyüm madde de bana iyi gelsin diye başlamadım yani. Öyle genelde öyle çok olmuyor. Hani var mesela çok mutlu oluyor arkadaşları gülüyor eğleniyor. Diyor ki niye, bende bu kadar mutlu olmak istiyorum? Diyor içiyor mesela. Ama benimki öyle çok olmadl. Daha çok uyum sağlamak için belki de merak ettiğim için öyle yani. Ama kötü bir dönemdeydim yani. (K., 32)

-Yani nasıl bir şey diye çok merak ettim. Biradan farkll, içkiden farkl olarak kokmuyor diye içmeye başladım. Öyle." (A., 17)

Genç bireylerde madde kullanan arkadaşı olanların, madde kullanan arkadaşı olmayanlara göre madde kullanım riskleri oldukça fazladır. Madde kullanan arkadaşı olan ergen, madde kullanımına 
özenebilmekte ve bu özenti ergenin madde denemesi ardından gelen madde bağımlılığıyla sonuçlanabilmektedir.

“-Herhangi bir nedenden dolayı değil benim maddeye başlama isteğim, tamamen özentilik arkadaş çevresi, merak onlardan sebep.” (Z., 16)

“-Onlar da içiyordu zaten içmeyenler de pek karışamıyordu, onlar da çocuk olduğu için zaten ne olduğunu çok bilmiyorlardı havalı görünüyordu." (P., 17)

Madde kullanan akran çevresinin yanı sıra ailede madde kullanıcısının olması da bağımlılığa iten bir diğer önemli faktör olarak karşımıza çıkmaktadır.

“-11 yaşındaydım, ilk evde kullandım, nasıl kullanıldı̆̆ını biliyordum, benim abim de madde bağımlısı, bu nasıl içiyor bende bir bakayım dedim o yüzden başladım. Tektim. Ben söyleyene kadar kimse beni aylkamad, çözemedi, ben söyledim anneme. 13-14 yaşlarında söyledim, o zamana kadar anlamadilar." (O., 17)

Akran grubunun madde kullanımıyla ilgili tutumları bireyin madde kullanımını önemli ölçüde etkilemektedir. Madde kullanımına yönelik olumlu tutuma sahip arkadaş grubuna dâhil ergenlerde madde kullanma riski daha yüksektir. Arkadaş grubuna bağlılığı yüksek kişilerde de madde kullanma riskinin fazla olduğu yapılan çalışmalarla ortaya çıkmaktadır (Ögel, Ermağan, Eke ve Taner, 2007). Görüşmecilere sorulan; “hayatınızdaki hangi süreçlerden sonra madde kullanmaya başladınız?" sorusuna B.'nin (19) verdiği cevap da göstermektedir ki madde kullanımında olduğu gibi maddenin temininde de akran grubunun etkisi yadsınamamaktadır.

“-Beni ailem siknyor dedim ölemiyorum madem dedim sigara mi içsem ne yapsam dedim arkadaşlarıma dedim ki ben artık hayattan nefret ediyorum, evden kaçacă̆ım dedim onlarda kaçma gel ben seni rahatlatacak bir şey vereyim dedi kaç para dedim 15 lira dedi adı ne dedim korex dediler." (B., 19)

Erkek arkadaşın veya akran grubunun madde kullanması ve kullanıma teşvik etmesi; "kullan, bir şey olmaz" gibi "cesaretlendirmelerde" bulunmaları da madde kullanım sürecinde önemli bir yer edinmektedir.

“-Bonzai kullandiğımda öldüm geri gelemeyeceğim filan demiştim, ailemi düşünmüş̧üm onun bana yaptıkları, çalıştım sıkıldım ondan sonra işte baya bir kötü şeyler oldu filan sonra erkek arkadaşımı düşündüm o da kullanıyordu kullan bir şey olmaz filan dedi bende kullanayım bari dedim. Kullandiğında her şey bitti filan diyorsun eve filan gidesin gelmiyor bir süre sonra annenle konuşmuyorsun, konuşmanı kesiyorsun baya bir değissik oluyorsun, ara sıra unutkanlık yapıyor bazen, bir arkadaşım böbreklerinden hasta olmuştu baya bir hastalık oluyor devamlı kullanırsan zararları çok." (B., 19)

Öte yandan Z. akran grubunun maddeyi bırakma sürecindeki etkisini şu şekilde anlatmaktadır:

“-Arkadaşına göre değişiyor aslında, kimileri dışladı kimileri benimle birlik olup aynı şeyi yaptı ama dışlayan daha çoktu.” (Z., 16)

\section{SONUÇ}

Madde kullanımına başlama noktasında birçok etken vardır. Bu etkenler arasında ebeveynlerin ve akranların rolünün de incelenmesi gerekmektedir. Her insan farklı dinamiklerin bir araya gelmesiyle bir madde bağımlısı olabilir. Gençler arasında ise olabilecek değişkenler arasında aile ve akran etkisi incelemeye değerdir. Bu çalışma da madde kullanmış genç kızlar arasında bağımlılık sürecine girme, devam etme ve bırakmada aile ve arkadaşlarının etkisini öğrenmek amacıyla yapılmıştır. Görüşmeciler Çocuk ve Ergen Madde Bağımlılığı Tedavi Eğitim ve Destek Merkezi'ne (ÇEMATEM) gelen 15-18 yaş arası kişiler ve Ayık Yaşamda Buluşalım Derneği (AYBUDER) ile Bağımsız Yaşam Derneği'ne (BAYDER) gelen 18-20 yaş arası danışanlar arasından rastgele seçilmiş 9 kişidir.

Alan çalışmaları arasında ergenin ailesi ve akranları ile ilişkisinin madde kullanımına etkisini inceleyen ve bu iki durum arasında anlamlı ilişki bulan çalışmalar mevcuttur (Yaman, 2014; Coşkun, 2008; Ögel 
ve Aksoy, 2006). Bununla birlikte Türkiye'de madde kullanan kızlar, erkeklere oranla daha az göz önünde olduğundan bu konu üzerine araştırma yapılması gerekmektedir.

Çalışma sonucumuza göre en çok kullanılan maddeler; korex, ekstazi, bonzaidir. Bunun dışında çakmak gazı, tiner, antidepresan, esrar da kullanılan maddeler arasındadır. Ayrıca görüşülen gençlerin neredeyse tamamında bu süreçte birden fazla madde kullanımı olduğu öğrenilmiştir. Farklı maddeleri eş zamanlı kullanma durumu da söz konusudur. Maddeyi temin etme ise ailelerinden aldıkları harçlıkla veya çalışarak kazandıkları parayla olmaktadır, bu süreçte hırsızlık yaparak madde aldığını ifade eden de olmuştur. Bunun yanı sıra maddeye ulaşamadığı süreçte kendisinden faydalanılmaya çalışıldığını belirten görüşmeciler de vardır. Gerek madde satın alınan torbacılar gerek kızın madde kullandığını bilen çevredeki erkekler tarafindan kızlara yönelik tacizler gerçekleşebilmektedir.

Yukarıda da bahsedilen yapılmış bir çalışmada (Coşkun, 2008) gençler arasında madde kullanımına başlanmasındaki en önemli nedenin aile içi sorunlar ve sağlıkl iletişimin yokluğu olduğu sonucuna varılmıştır. Yapılan görüşmeler esnasında da madde bağımlısı genç kızların aileleri ile ilgili en yaygın kanaatlerinin başında aile içi uygun olmayan iletişim yollarının varlığı ya da iletişimden kopuk bir aile ortamından geldiklerini düşünmeleri yer almaktadır. Genç kızın bir birey olarak aile içinde değer ve saygı görmeyişi, anne-baba ile derdini anlatacak ve sırrını paylaşacak düzeyde bir ilişki ve yakınlığının olmaması; genç kızın madde kullanımına başlamasındaki nedenler arasında gösterilebilir. Ailede sıcaklık ve şefkatin olmaması, ilişkilerin düşmanca ve kopuk yaşanması madde kullanımında bir başka etken olarak bu çalışmada karşımıza çıkmaktadır. Zira görüşme yapılan genç kızların maddeyi deneme ve bağımlı olma sürecinde sağlıklı ve uygun olmayan aile ilişkileri sıkça dile getirilmiştir.

Görüşme yapılan kişilerin bazılarının ailelerinde yaşadıkları bir başka önemli sorun ise aile içi ihmâl ve istismar olgusunun varlığıdır. Şiddet gören genç kızlar ebeveyne karşı sevgi ve güveni kaybederek aileden uzaklaşabilir. Parçalanmış ailelerdeki çocukların da madde kullanımına başlama ihtimali artmaktadır. Ebeveyn kaybı, boşanma vb. çeşitli sebeplerden dolayı anne-babanın birlikte yaşayamaması, çocukların akraba yanında veya yurtta kalması araştırmada aile yapısını değiştiren bir durum olarak karşımıza çıkmıştır. Bu konuyla alakalı çalışmalara baktığımızda ise bu bulgulara benzer olarak gençler üzerinde araştırma yapılmış (Bircan ve Erden, 2011) ve madde bağımlısı olan kişilerin daha reddedici ve olumsuz bir aile ortamında yetiştikleri ortaya konulmuş, yine benzer bir araştırmada (Denton ve Kampfe, 1994, akt. Bircan ve Erden, 2011) ise parçalanmış aileye sahip olmanın ve aile içinde çeşitli sorunların olmasının madde kullanımında önemli bir etken olduğu sonucuna ulaşılmıştır. Madde kullanımına başlanmasındaki etkenlerden bir diğeri ise ailede madde kullanan bireylerin varlığıdır. Örnek bir rolmodel ebeveyne sahip olamama, ailede bazı bireylerin varla yok arasında olması veya kardeşin madde kullanması genç kızları madde kullanımı ile karşı karşıya getirebilmektedir.

Madde kullanımı noktasında Yaman'ın (2014) yapmış olduğu bir çalışmada farklı ekonomik düzeye sahip gençler incelenerek maddi anlamda daha alt düzeyde sayılabilecek kişilerin üst gelir grubundaki bireylere göre daha fazla madde kullanımı davranışına sahip olduğu ortaya konulmuştur. Ailenin düşük sosyo-ekonomik düzeye sahip olmasının oldukça etkili olduğu söylenebilir. Maddi kaynaklarının yetersiz olması gençlerin toplumda eğitim, sağlık, sosyo-kültürel vb. faaliyetlerden yeterince faydalanamamalarına sebep olmaktadır. Araştırmamızda da yaşanan bu zor şartlar altında genç kızların kendilerini toplumda var etme çabasının madde kullanımı ile sonuçlanabildiği görülmüştür. Bununla birlikte ebeveynlerin uygun olmayan çocuk yetiştirme tutumları, çocukların psiko-sosyal gelişimine ciddi ölçüde zarar verebilir. Anne babanın çocuğa davranışlarında dengeyi sağlayamaması kişinin vereceği kararlarda oldukça etkili olabileceği için ebeveynlerin aşırı izin verici, ilgisiz ve reddedici davranışlar sergilemesinin genç kızlarda madde bağımlılığına sebep olduğu düşünülmektedir.

Bağımlılık sadece bireyi değil tüm aileyi etkileyen bir hastalıktır. Çocuğunun madde kullandığını öğrenmek ise aile için bir kriz durumudur. Katılımcılardan alınan bilgilere göre aileler çocuklarının madde kullandığını öğrendiğinde aile ilişkileri eskiye nazaran daha iyi bir seyir göstermiştir. Ailenin bu süreçte çocuklarına karşı takındığı tutum ve gösterilen davranışlar genç kızların yaşanılan süreci daha zararsız bir şekilde atlatmasına yardımcı olmaktadır. Bağımlılık tedavisindeki başarı bireye, aileye ve tedavi yöntemine göre değişir. Tedavide başarıyı arttıran önemli faktörlerden biri kişinin istekli ve kararlı olmasıdır. Bağımlı kendini değiştirmeye çalışırken, ailesi ise değişimleri kabul edici bir tutum sergilemelidir. Maddeyi bırakmaya karar veren gençler için aileden alacağı destek oldukça önemlidir. 
Nitekim görüşmeciler arasında aileden aldığ belirtenler olmuştur. Literatürdeki farklı araştırmalarda da (Yaman, 2014) bu durum ortaya konulmuş, ailenin gencin madde kullandığını öğrendikten sonraki tutumunun bırakma sürecini oldukça etkilediği belirtilmiştir.

Gençlerin madde kullanmaya başlamasında en az aile kadar önemli olan bir diğer faktör ise akran grubudur. Yapılan görüşmeler sonucunda genç kızların büyük çoğunluğunun madde kullanımına arkadaş ortamında ve arkadaşlarının cesaretlendirme veya baskılarıyla başladıkları öğrenilmiştir. Daha önce de bahsedildiği gibi bir araştırma raporuna göre de (TUBİM Raporu, 2009) madde \%38 oranında arkadaşlardan temin edilmektedir. Ayrıca ergen için bir akran grubuna dahil olmak ergenlik döneminin en önemli gelişmelerinden biridir. Ergenlikte bir akran grubuna dahil olabilmek aileye olan bağlılığın azalması anlamına gelebilir. Gençler için bu özgürlüğe kavuşabilmek, akran grubunca kabul edilmek demek grup üyelerinin yaptığı ve onun da yapmasını sözlü ya da sözlü olmayan yollarla ifade ettiği her şeyi yapmak anlamına gelebilir. Araştırmaya konu olan genç kızlar için de durum bundan farklı olmamakla birlikte büyük çoğunluğunun ailesiyle yaşadığı problemlerden kaçmak için akran gruplarına dahil olduklarını söylemek yanlış olmayacaktır.

Gençlerin isteklerinin ailede dinlenmemesi ya da önemsenmemesi genelde ebeveynlerin otorite sağlama yöntemlerinin bir sonucudur. İstek ve ihtiyaçlarının ailede karşılık bulmaması genç kıza kendini değersiz, boş, önemsenmeyen, varlığı bile bir yük olarak görülen, hayatta önemli bir rolü olmayan biri gibi hissettirebilmekte, bununla birlikte genç kızın ailesine karş1 sert tutumlar sergilemesine neden olabilmektedir. Genç kız bu durumun vermiş olduğu baskı ile kendisini ailesinden mahrum bırakmak istediği için aileden koparak akran gruplarına yönelebilir. Yani gencin arkadaşlarını ailesine tercih etmesinde aile içi iletişimin etkisinin büyük olduğu söylenebilir. Başka çalışmalarda ise (Atabek, 2002) bu duruma farklı bir açıdan bakılmış ve ergenlerin/gençlerin kendileriyle sosyal, ekonomik, ailevi vb. konularda benzer sorunlar yaşayan arkadaşlarıyla daha fazla yakınlaştığı belirtilmiştir. Yani buna göre gençler hem benzer sorunlara sahip kişilerle bir araya gelerek onların madde kullanım davranışından etkilenmekte hem de arkadaş etkisiyle maddeye başlayarak ilerleyen süreçte madde kullanımından kaynaklı benzer sorunlar yaşayabilmektedir.

Yapılan farklı araştırmalar (Atabek, 2002; Yaman, 2014, Ögel, Ermağan, Eke ve Taner, 2007, Ögel ve Aksoy, 2006, Santor, Messervey ve Kusumakar, 2000) arkadaş ortamında madde kullanan kişilerin varlığının gençlerin madde kullanımını etkilediğini göstermektedir. Görüşmeler sırasında ise; "arkadaş ortamına ayak uydurabilmek, onlar gibi olabilmek, ne hissettiklerini anlayabilmek" üzere ilk deneyimin yaşanması ile sıkça karşılaşılmışıı. Uyum sağlamak için denenen madde ise bağımlılığa atılan ilk adımdır. Ailesinin öğrenmesiyle genelde aileden destek gören genç, arkadaşlarının öğrenmesiyle sert bir tutumla karşılaşabilmektedir. Yapılan görüşmelerde madde kullanmayan arkadaşların durumu öğrenmesi sonucu kendisiyle görüşmeyi bıraktığını ifade edenler olmuştur. Bununla birlikte aile çoğunlukla gence destek olmaktadır.

Maddeyi denemede en önemli nedenlerden biri ise "merak ve özentilik"tir. Merak veya arkadaşına özenme sonucu maddeyi deneyen gençler bir bağımlıya dönüşür. İlk deneyime dair sorulan sorularda "mutlu olmak, dertlerini unutmak" cevabını verenlerin yanı sıra hiçbir beklentisi olmadığını, sadece meraktan kullandığını söyleyenler de olmuştur. Katılımcılar arasında ilk madde kullanımında yalnız olan neredeyse yoktur ve çoğunlukla evin dışında ve yanlarında akranları varken ilk deneyimi yaşamışlardır. Bu da maddeye başlamada akran etkisinin ne denli önemli olduğunu ispatlamaktadır.

Bırakma sürecinde çoğunlukla ailesinden destek alan kızlar farklı nedenlerden dolayı bırakma kararı almışlardır. $\mathrm{Bu}$ nedenler arasında tecavüz, maddi sıkıntı çekme, aileye yakalanma vb. sebepler bulunmaktadır. Aile içi ilişkilerinin zayıf olduğu ve sosyal destek sistemleri yetersiz olan ailelerden gelen genç kızlar maddeyi bırakma sürecinde daha fazla zorluk yaşamaktadır. Bu süreçte ailesinden kopuk olan genç kızlar çözümü kendisini içinde mutlu hissettiği ve değer gördüğü madde bağımlısı akran grubunda arayabilir.

Madde kullanmış/kullanmakta olan genç kızlar üzerine yapılan bu araştırma sonucunda ailenin tutum ve davranışlarının, gence gösterdiği ilgi ve sevginin onu nasıl etkilediği, akran gruplarının genç üzerindeki etkisi ve onlar için önemi öğrenilmeye çalış1lmıştır. Hem aile hem arkadaş çevresi oldukça önemli 
olmakla birlikte ergenlik dönemindeki olağan süreçlerden ötürü akran baskısı genç için daha önemli hale gelebilmektedir. Bununla birlikte akran baskısına karşı koymakta güçlük çeken ergenlere baktığımızda ailenin varla yok arasında olması, sevgi ve ilgiyi esirgemesi veya gence güvenmeyip çok fazla baskı yapması gibi ailesel etkileri görmezden gelmemek gerekir.

Gençlerin madde kullanımının önüne geçilmesi için hem ailelere hem de yetkililere önemli roller düşmektedir. Ailelerin çocuklarını sıkmadan takip etmesi, duygu-durumundaki veya bedenindeki değişiklikleri dikkate alması ve onların da kendileri gibi duyguları olan bir insan olduğunu unutmadan yaklaşması gerekmektedir. Akran gruplarının gencin üzerindeki etkisini göz ardı etmemeleri, arkadaş ortamının daha sağlıklı olması noktasında gence baskı yapmadan değişime teşvik etmeleri gerekmektedir. Kişinin sevgi ve ilgi ihtiyacını öncelikle ailenin karşılaması gerekir ki dışarıdan elde edilebilecek sevgi isteğiyle gençler yanlış yollara sapmasın. Aileye çocuklarını dinlemeleri, sevgilerini göstermeleri, onları eksik ve hatalarıyla da kabul ettiklerini hissettirmeleri, çocuklarına baskı kurmadan özel hayatını ve arkadaşlarını takip etmeleri önerilir. Bununla birlikte yetkililerin de madde konusunda hem aileyi hem de çocukları/gençleri uyarması gerekmektedir. Bu konuyla ilgili uzmanlarla birlikte etkili eğitimler düzenlenebilir, risk altındaki gruplar tespit edilerek belirli aralıklarla takip edilebilir. Gençlerin zamanlarını iyi değerlendirebilecekleri yeni mekanlar üretilerek vakitlerini madde kullanımının yaygın olduğu ortamlarda geçirmeleri önlenebilir.

\section{KAYNAKÇA}

Atabek, E. (2002). Erken büyüyen çocuklar. İstanbul: Altın Kitaplar Yayınevi.

Bilgiç, N. ve Günay, T. (2014). Ergenlerin sigara bırakma konusunda desteklenmesinde bir yöntem: Akran eğitimi. Turk Toraks Dergisi, 15, 104-105.

Bircan, S. ve Erden, G. (2011). Madde bağımlılı̆̆ı: Aile ile ilgili olası risk faktörleri, algılanan ebeveyn kabul-reddi ve çocuk yetiştirme stilleri. Çocuk Ve Gençlik Ruh Sağlı̆̆ Dergisi, 18(3), 211-222.

Coşkun, S. (2008). Uçucu madde kullanan ergenlerde bilinçlendirme eğitiminin etkinliği. Yayımlanmamış doktora tezi, Marmara Üniversitesi, İstanbul.

Drever, E. (1995). Using semi-structured interviews in small-scale research. A teacher's guide.

Erdamar, G. ve Kurupınar, A. (2014). Ortaöğretim öğrencilerinde görülen madde bağımlılığı alışkanlığı ve yaygınlığı: Bartın ili örneği. Sosyal Bilimler Dergisi. 16(1), 65-84.

Erdem, G., Eke, C.Y., Ögel, K. ve Taner, S. (2006). Lise öğrencilerinde arkadaş özellikleri ve madde kullanımı. Bă̆ımlılık Dergisi. 7(3), 111-116. 28 Nisan 2019 tarihinde www.bagimlilik.nethttp://ogelk.net/makale/arkadas ozellik.pdf adresinden erişildi.

Esen, B. K. (2003). Ergenlerin akran baskısı düzeyleri ve cinsiyetlerine göre sigara içme davranışlarının incelenmesi. Yayımlanmamış doktora tezi, Mersin Üniversitesi, Mersin.

Foster, K. ve Spencer, D. (2013). 'It's just a social thing': Drug use, friendship and borderwork among marginalized young people. International Journal of Drug Policy, 24(3), 223-230.

Gökler, R. ve Koçak, R. (2008). Uyuşturucu ve madde bağımlılı̆̆ı. Sosyal Bilimler Araştırmaları Dergisi, 1(1), 89-104.

Güleç, G., Köşger, F. ve Eşsizoğlu, A. (2015). DSM-5'te alkol ve madde kullanım bozuklukları. Psikiyatride Güncel Yaklaşımlar. 7(4), 448-460.

Kulaksızoğlu, A. (2011). Ergenlik psikolojisi. İstanbul: Remzi Kitabevi.

Longhurst, R. (2003). Semi-structured interviews and focus groups. N. Clifford, M. Cope, T. Gillespie ve S. French (Yay. haz.) Key methods in geography içinde (s. 143-156). USA: Sage.

Nieri, T., Kulis, S., Keith, V. M. ve Hurdle, D. (2005). Body image, acculturation, and substance abuse among boys and girls in the Southwest. The American Journal of Drug and Alcohol Abuse, 31(4), 617-639. 
Ögel, K. (2002). Bă̆ımlılı̆̆ önleme anne-baba-öğretmenler için kılavuz. İstanbul: IQ Kültür-Sanat Yayınc1lik.

Ögel, K. ve Aksoy, A. (2006). Tutuklu ve hükümlü ergenlerde madde kullanımı. Bağımlılık Dergisi. $8(1), 11-17$.

Ögel, K., Ermağan, A., Eke, C. Y. ve Taner, S. (2007). Madde deneyen ve denemeyen ergenlerde sosyal aktivitelere katılım: İstanbul örneklemi. Bağımlılık Dergisi, 8, 18-23.

Ögel, K. ve Tamar, G. D (t.y). Aile, bağımlılık ve aileye yaklaşım, 3-14.

Ögel, K., Taner, S., Tosun, M., Liman, O. ve Demir, T. (2006). Juvenile offences among hospitalized adolescent inhalant users in İstanbul: A comparison regarding place of residence. Journal of Psychoactive Drugs, 38(3), 297-304.

Ögel, K., Tanı ve değerlendirme. 29 Nisan 2019 tarihinde http://www.ogelk.net/Dosyadepo/tani.pdf adresinden erişildi.

Özmen, F. ve Kubanç, Y. (2013). Liselerde madde bağımlılığı mevcut durum ve önerilere ilişkin okul müdürleri ve öğretmenlerin bakış açıları. Turkish Studies. 8(3), 357-382.

Santor, D. A., Messervey, D. ve Kusumakar, V. (2000). Measuring peer pressure, popularity, and conformity in adolescent boys and girls: Predicting school performance, sexual attitudes, and substance abuse. Journal of Youth and Adolescence, 29(2), 163-182.

Satan, A. (2011). Ergenlerde akran baskısı, benlik saygısı ve alkol kullanımı arasındaki ilişkilerin incelenmesi. Marmara Üniversitesi Atatürk Eğitim Bilimleri Dergisi. 34, 183-194.

Schinke, S. P., Fang, L. ve Cole, K. C. (2008). Substance use among early adolescent girls: Risk and protective factors. Journal of Adolescent Health, 43(2), 191-194.

Temel, Z. F. ve Aksoy, A. (2001). Ergen ve gelişimi; Yetişkinliğe ilk adım. Ankara: Nobel Yayın Dağıtım.

TUBİM EMCDDA Türkiye Ulusal Temas Noktası, EMCDDA 2008 Yılı Türkiye Raporu, (2009), Ankara. $\quad 29 \quad$ Nisan $2019 \quad$ tarihinde http://www.narkotik.pol.tr/TUBIM/Documents/TURKIYE\%20UYUSTURUCU\%20RAPORU\%20 2008 SON.pdf adresinden erișildi.

Türkcan, A. (1998). Türkiye'de madde kullananların profili: Hastane verilerinin incelenmesi. Düşünen Adam. 11(3), 56-64.

$\begin{array}{llll}\text { Türk Dil } & \text { Kurumu, } & 31.03 .2019 & \text { tarihinde }\end{array}$ http://www.tdk.gov.tr/index.php?option=com_bts\&view=bts\&kategori1=veritbn\&kelimesec $=6973$ adresinden erişildi.

T.C. İçişleri Bakanlığı Emniyet Genel Müdürlüğü Narkotik Suçlarla Mücadele Daire Başkanlığı. (2018). Türkiye Uyuşturucu Raporu, Ankara. 29 Nisan 2019 tarihinde http://www.narkotik.pol.tr/Duyurular/Documents/2018\%20TURKIYE\%20UYUSTURUCU\%20R APORU.pdf adresinden erișildi.

United Nations, (2012). A concise report, world population monitoring; Adolescent and youth. 28 Nisan 2019 tarihinde https://www.un.org/en/development/desa/population/publications/pdf/fertility/12_66976_adolescent s_and_youth.pdf adresinden erişildi.

Uzbay, İ. T. (1996). Madde bağımlılığı. Bilim Teknik Dergisi. 4, 20-26.

Vatandaş, C. (2015). Türkiye'de gençlik ve uyuşturucu madde sorunu. İstanbul: Sosyal, Ekonomik ve Kültürel Araştırmalar Merkezi (SEKAM).

Yaman, Ö. M. (2014). Uyuşturucu madde bağımlısı gençlerin aile içi ilişkilere yönelik görüşleri: Esenler-Bağc1lar örneği. Türkiye Yeşilay Cemiyeti. 1(1), 99-132. 
Yörükoğlu, A. (1978). Çocuk ruh sağllğı: çocuğun kişilik gelişimi yetiştirilmesi ve ruhsal sorunları. Ankara: Türkiye İş Bankası Kültür Yayınları. 